\title{
Analyze the Expression of Cytokeratin 5 on the Epithelial Cells of the Buccal Mucosa in Batik Workers
}

\author{
Juni Handajani ${ }^{1}$, Dhinintya Hyta Narissi ${ }^{2}$ \\ ${ }^{1}$ Department of Oral Biology, Faculty of Dentistry, Gadjah Mada University, Sekip Utara, Bulaksumur, Yogyakarta, Indonesia \\ ${ }^{2}$ Faculty of Dentistry, Gadjah Mada University, Sekip Utara, Bulaksumur, Yogyakarta, Indonesia
}

\begin{abstract}
The industry of batik is often use synthetic dyes as azo. Azo dyes contain naphtol and diazonium salts that are toxic to the tissue when exposed via inhalation, swallowing or direct contact. Some preliminary studies mentioned the exposure on the azo dyes batik could be expected to cause abnormalities in the buccal mucosal epithelial cell nuclei marked increase in the frequency of micronucleus, karyolisis, and pyknosis. Objective: the purpose of this study was to analyze the expression of cytokeratin 5 on the epithelial cells of the buccal mucosa in batik workers Yogyakarta. Material and Methods: the study included 30 male subjects were divided into 2 groups: 15 subjects exposed to azo dyes and 15 subjects as control. Criteria for subject were batik workers exposed azo dyes in The Unit of Coloring at batik home industry Yogyakarta, while control is not exposed to azo dyes. Buccal mucosal epithelial cells were swabbed using cytobrush. Analysis of the expression of cytokeratin 5 in the buccal mucosal epithelial cells was used monoclonal antibody cytokeratin 5 (Biocare Medical, USA) and immunohistochemical method (ABC Staining Kit, ImmunoCruz, Santa Cruz Biotechnology, USA). Data were analyzed using independent t-test. Results: the results showed the expression cytokeratin 5 of epithelial cells buccal mucosa was significantly higher in batik workers group than the control (p <0.05). Conclusion: It is concluded that exposed azo could increase the expression of cytokeratin 5 in the epithelial cells of the buccal mucosa batik workers in Yogyakarta.
\end{abstract}

Keywords: cytokeratin 5, epithelial cell, buccal mucosa, azo dye, batik worker

\section{Introduction}

Oral cavity is port d'entry of toxic and non toxic substance to the body, so susceptible to pathological change. Oral mucosa is demarcating oral cavity consisting of two basic layers that are separated by a basement membrane (basement membrane). Both the base layers are stratified squamous epithelium on the outer and inner layer of connective tissue (lamina propria). Some parts known to have a third layer (submucosal) are found between the lamina propria adjacent to the bone (palate) or muscles (cheeks and lips). Submucosal tissue is composed of loose connective tissue containing nerves and blood vessels, also glands salivarius $[1,2]$.

Function of oral mucosal protects mechanically against shear and tensile stress (compressive and shearing strength) providing defense against microorganisms, toxins, and some antigens contributing to the immunological defense both humoral and cell-mediated. Salivarius glands in the oral mucosa have function to secrete saliva which has several roles, there are lubrication and buffer activity and provide some antibodies $[1,3]$

Variation regional of the oral mucosa is associated with the degrees and types of pressure during mastication, speech and facial expressions. Oral mucosal structure varies according to the thickness of the epithelium, the degree of keratinization, connective tissue interface complexity to the epithelium, lamina propria and the composition of the existing or the absence of submucosal [1]. Classification of oral mucosa is divided into masticatory, lining and specialized. Buccal mucosa is categorized lining, can be distended and bonded to the surrounding tissue structure through connective tissue which is rich in elastin. Oral mucosa is consisting 60\% lining, $25 \%$ masticatory and the remaining $15 \%$ specialized $[1,2,4]$.

Characteristics of lining epithelium mucosa are not keratinized and slightly under pressure. Differences between lining epithelial cells and keratinization epithelium are the surface layer of cells lining epithelium has little or no keratohyalin granules, filagrin protein and loricrin, but contains involucrin $[1,5]$.

Cytokeratin $(\mathrm{CK})$ is a protein that contains keratin intermediate filaments. The function of this protein is a component of the cytoskeleton and to contact the cell (desmosome and hemidesmosome) in epithelial tissues. Each product cytokeratin gene family is divided into neutral or basic type II cytokeratin (numbers 1-8) and the acidic type I cytokeratin (numbers 9-20). Cytokeratin usually found in pairs and type I have a shorter size. Specific distribution of cytokeratin 5 and 15 in epithelial are usually confined to the basal and parabasal layers although cytokeratin 14 may also be expressed by suprabasal keratinocytes. Cytokeratin 1 and 10 are found in the suprabasal layers of masticatory mucosa. Mucosal lining, mainly suprabasal keratinocytes stained for CK 4 and 13. In the epithelium lining the soft palate expressed CK 7, 8, and $18[1,5]$

Primary function of cytokeratin is to protect the epithelial cells of the pressure (stress) mechanical and non-mechanical resulting in cell death. The role of cytokeratin includes signaling when a cell responds to stress, apoptosis and other specific functions. Several human diseases are related to the alleged involvement of cytokeratin. Cytokeratin is increasingly widely used as a tumor marker for the purpose 


\section{International Journal of Science and Research (IJSR) \\ ISSN (Online): 2319-7064}

Index Copernicus Value (2013): 6.14 | Impact Factor (2014): 5.611

histodiagnosis and management of certain cancers. Cytokeratin proteins are used as a tumor marker for certain specific network. Cytokeratin expression can describe the differentiation of epithelial cells $[1,5,6]$.

Human oral mucosa describes the best illustration of the expression patterns of differentiation depending cytokeratin by stratified epithelium. Various areas on the oral mucosa showed differences in the level of differentiation and keratinization depends on various expression of cytokeratin. All areas of the oral mucosa express cytokeratin 5 and 14 . The epithelium buccal mucosa as non keratinization expressed cytokeratin 4 and 13 in the suprabasal layer while the basal layer of cytokeratin 5 and 14. The gingiva as keratinized epithelium expressed cytokeratin 1 and 10 in the suprabasal layers whereas in the basal layer showed expression of cytokeratin 5 and $14[5,6]$.

Batik is a fabric dyed with natural or synthetic dyes with the beauty of the art can be seen from patterns and motives. The process of making batik uses natural and synthesis dyes. Natural dyes can be obtained from the extracts of various parts of plants such as roots, wood, leaves, seeds or flowers. Some plant source that can be used by batik e.g Indigo (Indigofera tinctoria), coconut (Cocos nucifera), tea (Camellia sinensis), secang (Caesaslpinia Sapapan Lin), turmeric (Curcuma domestica val), or onion (Allium ascalonicium L). Recently the usage of synthesis dyes is increase because of the difficulty to obtain natural dyes. Synthetic dyes are often used in batik process, that are naphthol, indigosol, remazol, and procion $[7,8]$.

Chemicals are often used in the process of batik, especially to open the pores of the fabric (the mordanting) and a color fixation. Chemicals used in the batik industry include pigments, dyes, and wax [9]. Textile dyes generally are made of azo compound and benzene derivatives. Benzene is known to be difficult to degrade because the degradation process requires a fairly long time. Chemicals in the batik industry can cause irritation to skin, eyes, and cause disturbances in the respiratory system. Azo compound will be a source of disease because of its carcinogenic and mutagenic [10, 11]. Previous study suggested that exposure to azo dyes significantly increasing the frequency of micronuclei [12], karyolisis [13], and pyknosis [14] in buccal mucosal epithelial cells of batik workers in Yogyakarta with the duration of exposure more than 5 years.

Cytokeratin expression is associated with the stage of maturation on mucosal tissue [15]. Changes in protein expression of cytokeratin showed early changes that may lead to the differentiation of tissue malignancy. Moreover, the expression of cytokeratin has an important role as a diagnostic tool of oncology $[1,5]$.

To our knowledge, no study has been carried out on the effect of azo exposure on the buccal mucosa of batik workers. Thus, the aim of this study was to analyze the expression of cytokeratin 5 on the epithelial cells of the buccal mucosa in batik workers Yogyakarta.

\section{Material and Method}

\section{Subject and Study Design}

The subject consisted of 30 men, divided into 2 groups, aged range 18-40 years old. They were 15 subjects exposed azo in The Unit of Coloring at batik home industry Yogyakarta and 15 as a control. Informed consent according to Helsinki II was obtained from each participant.

\section{Intervention and Assessment}

Approval ethical clearance from the Ethics Committee Faculty of Dentistry, Gadjah Mada University (Number: 00261/KKEP/FKG-UGM/EC/2015) on May 15, 2015. Subjects were asked to rinse prior to remove debris from the oral cavity. Cytobrush was moistened with $0.09 \% \mathrm{NaCl}$. Buccal epithelial cells were swabbed using cytobrush. Swab was done by turning the cytobrush in the direction of at least $360^{\circ}$ on the right buccal mucosa. The same procedure was performed on the left buccal mucosa.

The epithelial cell of buccal mucosa was then swabbed on poly-L-lysine glass object to be rotated in the opposite direction from the direction of rotation on the buccal mucosa The procedure followed by similar steps in the swab left buccal mucosa. Fixation was done on the preparations using a solution of methanol-acetic acid $(3: 1)$ and made shortly before use. Fixation intended to prevent autolysis and maintain cell element that did not change the shape or size Glass object was evaporated for 1 day to completely dried.

\section{Immunohistochemical Staining}

Samples were washed with PBS 3 times each for 5 minutes. The procedure was then performed using a blocking BSA $0.1 \%$ and $0.25 \%$ Triton for 20 minutes, then washed using with PBS 3 times each for 5 minutes. Incubation was carried out using a monoclonal antibody anti cytokeratin 5 (Biocare Medical, USA) for 24 hours at $4{ }^{\circ} \mathrm{C}$. Samples were washed using PBS 3 times each for 5 minutes.

Samples were stained using immunohistochemical method (ABC Staining Kit, ImmunoCruz, Santa Cruz Biotechnology, USA). Samples were incubated using a secondary antibody for 20 minutes in room temperature. The procedure followed by immersion in a substrate buffer for 20 minutes in room temperature.

Staining was used DAB around 20 minutes. Positive result was expressed brown colour on both nuclear and cytoplasmic cell. Samples were observed using a light microscope magnification of 200 times and a computer monitor with a magnification of 100 times. Each sample was collected at least 100 epithelial cells. Observation was done by counting positive cell of cytokeratin 5 .

\section{Statistical Analysis}

The normal of the data and the homogeneity of variance were verified the Shapiro-Wilk and the Levene's test respectively. The data of expression cytokeratin 5 epithelial buccal mucosa cells was then compared using independent t-test. In all the analysis, the level of significance was set at $p<0.05$ 


\section{International Journal of Science and Research (IJSR) \\ ISSN (Online): 2319-7064 \\ Index Copernicus Value (2013): 6.14 | Impact Factor (2014): 5.611}

and was considered as significant. The calculations were handled with SPSS 12.0 software for Windows (SPSS Inc; Chicago, IL, USA).

\section{Result}

The expression of cytokeratin 5 was shown in cell nucleus and cytoplasm epithelial buccal mucosa cell (Figure 1). Positive expression of cytokeratin 5 was observed in both exposed to azo and control groups.
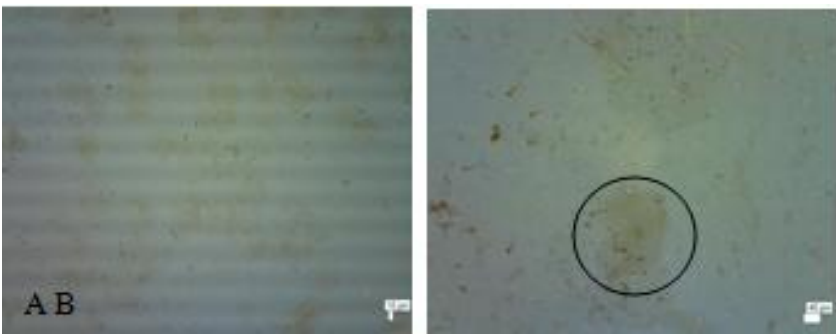

Figure 1: A. Expression of cytokeratin 5 was observed at the entire epithelial cell of buccal mucosa in exposed to azo group. B. Positive expression was shown brown in nucleus and cytoplasm (circle). There was vacuola in the cytoplasm cell.
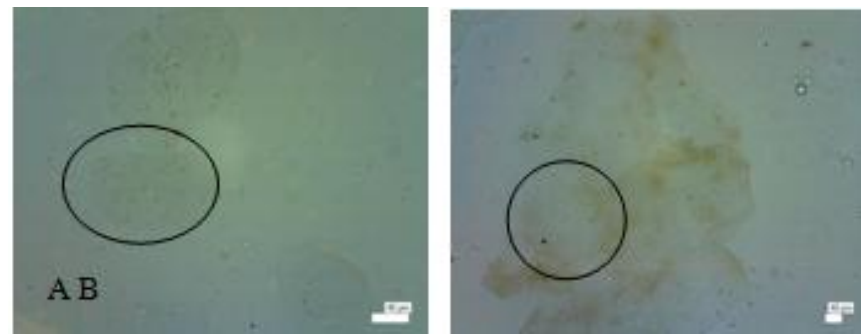

Figure 2: Expression of cytokeratin 5 was in exposed to azo group (A), showed brown colour in both nucleus and cytoplasm, and vacuola in the cytoplasm (circle). The control group (B) observed brown colour only in the cytoplasm of the cell while the cell nuclei was blue.

Mean and standar deviation the number of expressed cytokeratin 5 in the epithelial buccal mucosa cells were shown in Table 1.

Table 1: Mean and standard deviation of the number epithelial cell expressed cytokeratin 5 in exposed to azo and control groups

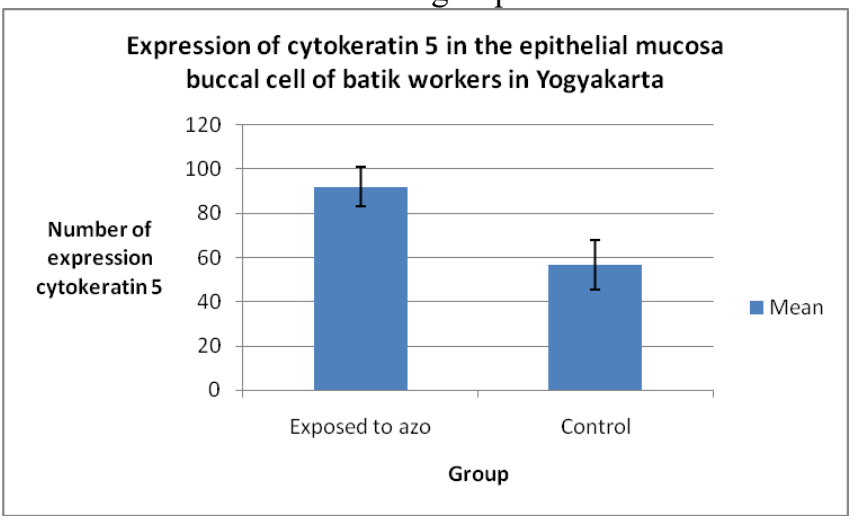

Table 1 showed mean the expression of cytokeratin 5 in the buccal mucosal epithelial cells of batik was higher than control. Normality data was calculated using the ShapiroWilk. The results of the normality data showed a group of exposed to azo in batik workers $\mathrm{p}=0.964$ and control $\mathrm{p}=$ 0.759 . These results indicated the data were normally distributed $(p>0.05)$. Calculation of data homogeneity was used Levene's test showed $p=0.062(p>0.05)$ or data homogeneous. Furthermore, the data were tested using independent t-test $\mathrm{p}=0.00(\mathrm{p}<0.05)$. The result indicated the number of epithelial buccal mucosal cells that expressed cytokeratin 5 in batik workers were significantly different than the control.

\section{Discussion}

Observation of the effect of genotoxic, cytotoxic, an indication of exposure to chemicals, and toxic response can be performed using epithelial buccal cell exfoliation technique. Cytokeratin is very useful for tumor markers in oncology. Expression of cytokeratin in this study showed that the pattern did not the normal pattern. This pattern can be observed in Table 1, which showed increasing the expression of cytokeratin 5 in the epithelial buccal mucosal cells in the group exposed to azo batik workers. According to Garant [5] that cytokeratin 5 was not expressed on the superficial epithelial cells of the buccal mucosa. Buccal mucosa as lining mucosa was not keratinized. Expression of cytokeratin 5 and 14 observed in all types of basal cell keratinization and non-keratinization and the expression would be decreased in suprabasal layer. This study also showed the visible expression of cytokeratin 5 in the control group in small number (Table 1). The condition was probably due to posttranscriptional regulation of mitosis process. The number of expression of cytokeratin 5 were elevated in the batik workers group suspected pathological changes in circumstances on the buccal mucosa.

Increasing the number of epithelial cells expressed cytokeratin 5 in the buccal mucosa batik worker was significantly higher than the control may due to exposure to the azo material that always inhaled while working. Subjects had worked in the Unit of Coloring batik for at least five years so that the possibility of exposure time appropriate materials azo long time since they worked. Azo dyes entered to the the body through inhalation, then the dye was metabolized, resulting in abnormalities in the cells of epithelial the buccal mucosa. The use of azo dyes in batik that exceed normal limits suspected as the cause of an increase in the expression of cytokeratin 5 in batik workers. The use of azo dyes with a safe threshold value according to Decree No. LH 51 / MENLH / 10/1995 was in the range 200$400 \mathrm{mg} / \mathrm{L}$, with the prohibition of the use permit by Permenkes No. 722 / Menkes / Per / IX / 2008 due to carsinogenic element. Results of the interviews indicated the use of azo dyes was about $10-15 \mathrm{~g} / \mathrm{L}$, or about 20 times higher than the maximum safe limit recommended by the Ministry of Environment.

The abnormality in the cells exposed to azo in batik worker also showed for vacuola in the cell cytoplasm (Figure 1 and 


\section{International Journal of Science and Research (IJSR) \\ ISSN (Online): 2319-7064}

Index Copernicus Value (2013): 6.14 | Impact Factor (2014): 5.611

2). It was suspected the workers were always exposed to azo, these substances were likely to enter and settle in the oral cavity, which could lead to cell changes, especially if the unprotected substrate was carcinogenic [16]. Studies conducted by Camargo-Ventura et al. [11], the cell abnormalities caused by exposure to azo dyes showed chromosome was missing. The missing chromosome could cause inactivation effect aneugenik namely bundle mitosis. The inactivation would avoid chromosomes migrate toward the poles of the cell, blocking the path of metaphase. Chromosomes would be pressed to form a distinctive character called metaphase chromosomes or C-metaphase. At the stage of $\mathrm{C}$-metaphase, the material was able to control the exposure aneugenik bundle and forming mitotic cell abnormalities. The mechanism was thought to occur also in the form of vacoula cell abnormality state in the cytoplasm.

Positive expression of cytokeratin 5 showed brown colour in both the nucleus and cytoplasm of the buccal mucosa cell (Figure 2A) in exposed to azo batik workers group. In the control group only observed positive expression in the cell cytoplasm (Figure 2B), while in the cell nucleus was blue colour. The condition may cause the damage to the DNA in the basal cells that occurs when there was a change of epithelial cell differentiation patterns of differentiation. Cytokeratin expression was associated with epithelial cell differentiation stage buccal mucosa [17]. This study also supported previous results that exposured to azo dyes in batik workers in Yogyakarta was significantly effect on the increase in the frequency of micronuclei, karyolisis, and pyknosis the buccal mucosal epithelial cells. Increased frequency of micronuclei, pyknosis cell nucleus and karyolisis indicated damage of DNA nucleus [12, 13, 14].

Another possibility of changes in the pattern of differentiation in epithelial buccal mucosal cells in batik workers was a system of self protection to workers who were still very minimal. This could be seen when all workers in Unit of Colouring batik did not use personal protective equipment so that they could be vulnerable to get the risk exposure of azo dyes. Therefore, we concluded that exposure to azo colour can enhance the expression of cytokeratin 5 in the epithelial cells of the buccal mucosa batik workers in Yogyakarta.

\section{Acknowledgment}

This study was supported by Grant (Dana Masyarakat) from Faculty of Dentistry, Gadjah Mada University, Yogyakarta, Indonesia. We would like to thank you to Mufidana Azis and Aurita Siwi Rahmawati who helped to collect the samples.

\section{Compliance with Ethical Standards}

Conflict of Interest: Author Juni Handajani declares that she has no conflict of interest. Author Dhinintya Hyta Narissi declares that she has no conflict of interest.

Funding: The work was supported by Grant (Dana Masyarakat) Contract No. 3443/KG/PP/ 2015 from Faculty of Dentistry, Gadjah Mada University, Yogyakarta, Indonesia.

Ethical approval: This article contains studies with human participants performed by the authors. The procedure in this study was approved from the Ethics Committee Faculty of Dentistry, Gadjah Mada University (Number: 00261/KKEP/FKG-UGM/EC/2015) on May 15, 2015.

Informed consent: All participants have agreed to participate in this study by signing the formal consent.

\section{References}

[1] B. Berkovitz, B. Moxham, R. Linden, A. Sloan, "Oral Biology Master Dentistry," Vol. 3, Churchill Livingstone, London, 2011.

[2] J.K. Avery, D.J. Chiego Jr, "Essential of Oral Histology and Embryology," $3^{\text {rd }}$ Ed, Mosby Elsevier, USA, 2006.

[3] T. Cate, "Oral Histology: Development, Structure, and Function," Mosby Elsevier, Missouri, 2008.

[4] A. Nanci, "Ten Cate's Oral Histology: Development, Structure, and Function," $8^{\text {th }}$ Ed, Elsevier, Canada, 2013.

[5] P.R. Garant, "Oral Cells and Tissues," Quintessence, Chicago, 2003.

[6] S. Sawant, D. Chauker, A.R. Cruz, M. Vaidya, "Cytokeratins as Prognostic Markers for Human Oral Cancer: Immerging Trends," International Journal of Medical and Biologica Frontiers, 2004; XVII (11), pp. 190-195, 2004.

[7] B. Gratha, "Easy Guide to Learning Batik (Panduan Mudah Belajar Membatik)," Demedia Pustaka, Jakarta, 2012.

[8] I. Dani, "Stylish with Beautiful Batik and Weaving (Cantik Bergaya Dengan Batik dan Tenun)," Niaga Swadaya, Jakarta, 2012.

[9] S. Widodo, I.K. Sinarya, Iswahyudi, "Staining of Nature Materials on Lurik Batik works "Batik Natural Sarwidi" (Pewarnaan Bahan Alam pada Batik Lurik Karya "Batik Natural Sarwidi") Bayat Klaten Jawa Tengah,” Journal Universitas Negeri Yogyakarta, I (2), pp. 7-13, 2012.

[10]E. Widjajanti, T.P. Regina, U.M. Prajonto UM, "Pattern of Zeolit Adsorption against Methyl Red and Orange Azo Dyes (Pola Adsorpsi Zeolit Terhadap Pewarna Azo Metil Merah dan Jingga)", In Proceeding Seminar Nasional Penelitian, Fakultas MIPA Universitas Negeri Yogyakarta, pp. 1-14, 2011.

[11]B de C Camargo-Ventura, P.P.P. Maltempi, M.A. Marin-Morales, "The Use of the Cytogenetic to Identify Mechanisms of Action of an Azo Dye in Allium Cepa Meristematic Cells," Journal of Environmental and Analytical Toxicology, I (3), pp. 5-12, 2011. doi: 10.4172/2161-0525.1000109

[12]D.H.N. Latief, J. Handajani, R.T.C. Tandelilin, "(Analysis micronucleus on buccal mucosa of batik workers in Yogyakarta) Analisis Frekuensi Mikronukleus Usapan Epitel Mukosa Bukal Pengrajin di Yogyakarta Batik Akibat Paparan Pewarna Azo," 2014. [Online]. Available: http://etd.repository.ugm.ac.id/. [Accessed: March 27, 2015]. 
[13]M. Aziz, J. Handajani, R.T.C. Tandelilin RTC, "Exposure effect of azo dyes in the increase of karyolisis nucleus in buccal mucosal epithelial cells of batik workers (Efek paparan bahan pewarna azo terhadap perubahan inti sel kariolisis epitel mukosa bukal pengrajin batik)," 2014. [Online]. Available: http://etd.repository.ugm.ac.id/. [Accessed: March 27, 2015].

[14] A.S. Rahmawati, J. Handajani, A.L. Jonarta, "The frequency of pyknosis cell in the buccal mucosa epithelium caused by azo dyes (Analisis Frekuensi Inti Sel Piknosis Epitel Mukosa Bukal pada Pengrajin Batik Akibat Paparan Bahan Pewarna Azo)," 2014. [Online]. Available: http://etd.repository.ugm.ac.id/. [Accessed: March 27, 2015].

[15]I. Garzon, D. Serrato, O. Roda, M. Del Carmen Sanchez-Quevedo, M. Gonzales-Jaranay, G. Moreu, R. Nieto-Aguilar, M. Alaminos, A. Campos, "In vitro cytokeratin expression profiling of human oral mucosa substitutes developed by tissue engineering," The International Journal of Artificial Organs, XXXII (10), pp. 711-719, 2009.

[16] N. Holland, B. Claudia, M. Fennech, B. Stefano, Z. Errol, K. Siegfried, "The Micronucleus Assay in Human Buccal Cell as A Tool for Biomonitoring DNA Damage: The HUMN Project Perspective on Current Status and Knowledge Gaps," Mutation Research, 659 (1-2), pp. 93-108, 2008. doi:10.1016/j.mrrev.2008.03.007

[17] G.R. Ogden, "Cytokeratins as tumour markers," Oral Disease, VI, pp. 57-59, 2000.

\section{Author Profile}

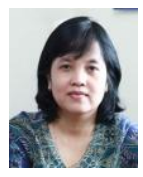

Juni Handajani was graduated as a dentist, Master of Dental Science, and Doctoral degree from Faculty of Dentistry, Gadjah Mada University, Indonesia. In March 23, 2011, she received PhD degree in Dental Science from Niigata University Japan. She is as a lecturer and researcher at Department of Oral Biology, Faculty of Dentistry Gadjah Mada University since 1998 until now. 